\title{
Morphology and Physical Properties of Ceramic Hollow Fibre Membrane: Effect of Different Bore Fluid Flow Rates
}

(Sifat Morfologi dan Fizikal Membran Serabut Berongga Seramik: Kesan Perbezaan Kadar Aliran Larik Cecair)

\author{
Siti SAlWA Alias, ZaWATI HARUN*, AHMAd NAZREEN AHMAd ISMAIl \& NOOR HASLIZA KAMARUdiN
}

\begin{abstract}
The study on ceramic hollow fibre membrane (CHFM) has been extensively explored. In this study, the CHFM was fabricated via extrusion combined with phase inversion and sintering method using silica, alumina with polyethersulfone binder and N-Methyl-2-pyrrolidone solvent at different bore fluid flow rates $\left(10,15\right.$ and $\left.20 \mathrm{~mL} \mathrm{~min} \mathrm{~m}^{-1}\right)$ and sintered (1200 $\left.{ }^{\circ} \mathrm{C}\right)$.

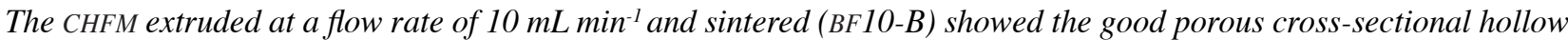
surface compared to the dense agglomerated surface of BF15-B and BF20-B. The highest Rq (82.1 $\mu \mathrm{m})$ and Ra (67.8 $\mu \mathrm{m})$ were obtained from $B F 10-B$ based on topography analysis which corresponded to the higher pore entrances of the membrane. The porosity decreased inversely proportional with the density as the bore fluid flow rate increased confirming that the suppression of un-solidified particles in the inner region cannot occur completely at a high bore fluid flow rate and produced dense membrane. The fabricated CHFM in this study has the broad potential to be applied as a membrane for water separation since it meets the minimum requirement of a commercial ceramic membrane.
\end{abstract}

Keywords: Alumina; bore fluid; ceramic membrane; flow rate; silica

\section{ABSTRAK}

Kajian membran serabut seramik (CHFM) telah diterokai secara meluas. Dalam kajian ini, CHFM dibuat melalui penyemperitan yang digabungkan dengan penyongsang fasa dan kaedah pensinteran dengan menggunakan silika, alumina dengan pengikat polietersulfon dan pelarut N-Metil-2-pirolidon pada kadar larik cecair yang berbeza (10, 15 dan $20 \mathrm{~mL}$ min $\left.^{-1}\right)$ dan disinter $\left(1200^{\circ} \mathrm{C}\right)$. CHFM yang diekstrusi pada kadar aliran $10 \mathrm{~mL} \mathrm{~min}^{-1}$ dan disinter (BF10-B) menunjukkan permukaan keratan rentas berongga yang baik berbanding dengan BF15-B dan BF20-B yang mempunyai permukaan padat dan bergumpal. Nilai Rq tertinggi $(82.1 \mu \mathrm{m})$ dan Ra $(67.8 \mu \mathrm{m})$ diperoleh daripada BF10-B berdasarkan analisis topografi menunjukkan bukaan liang membran yang tinggi. Keliangan yang berkurangan berkadar songsang dengan ketumpatan kadar larik cecair yang meningkat mengesahkan bahawa penekanan zarah yang bersatu di kawasan dalam tidak dapat berlaku sepenuhnya pada kadar larik cecair yang tinggi dan menghasilkan membran yang padat. CHFM yang dibuat dalam kajian ini berpotensi untuk digunakan sebagai membran untuk penapisan air kerana ia memenuhi keperluan minimum membran seramik komersial.

Kata kunci: Alumina; kadar aliran; larik cecair; membran seramik; silika

\section{INTRODUCTION}

The combination of extrusion with phase inversion and sintering is one of the most prominent methods used to produce ceramic hollow fibre membrane (CHFM) with the controllable desired design of tubular configuration, the higher area per volume ratio as compared to flat, planar and disc configuration (Hubadillah et al. 2018b; Lee et al. 2016). Also, one of the important parameters that vary in extrusion is the bore fluid (internal coagulant) flow rate (Kingsbury \& Li 2009; Tan et al. 2011; Wang \& Chung 2012). This refers to the rate in which dope will be extruded from the tube-in-orifice spinneret of the hollow fibre spinning machine. For example, the morphology of perovskite CHFM fabricated by this technique is transformed from multi-dense layers to one single dense layer using a $20 \mathrm{~mL} \mathrm{~min}^{-1}$ flow rate (Tan et al. 2011). Wang and Chung (2012) found that the different flow rate $(7$ to $11 \mathrm{~mL} \mathrm{~min}^{-1}$ ) affected the average bore diameter and morphology of CHFM based on polymer and lotus-rootlike multi-bore hollow fibre. Other studies varied the flow

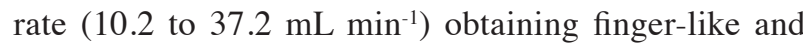
sponge-like structures but were limited on $\mathrm{Al}_{2} \mathrm{O}_{3}$ based CHFM (Kingsbury \& Li 2009).

For the past few decades, modification on ceramic membrane has been actively explored towards improving its ability to remove impurities from contaminated (Hubadillah et al. 2017a) water and gas separation (Ismail $\&$ David 2001). Ceramic membranes offer a vast array of advantages compared to polymer membranes concerning formational stability, thermal stability, wear resistance and chemical resistance (Harabi et al. 2014). Ceramic hollow fibre membranes (CHFMs) are a type of synthetic membrane comprising of a semi-permeable barrier in the form of hollow fibre. The CHFM is preferable given 
its practical application including high surface area per unit volume, small diameters of fibres $(\sim 200 \mu \mathrm{m})$, better flow profile and in accordance with the design of existing reactor structure (Maaskant et al. 2018; Zhu et al. 2015). Most commercial CHFMs are packed into cartridges which can be used for different types of liquid and gaseous separations. Typically, the CHFM is fabricated by using metal oxide such as silica $\left(\mathrm{SiO}_{2}\right)$ (Bao-li et al. 2018), alumina $\left(\mathrm{Al}_{2} \mathrm{O}_{3}\right)$ (Maaskant et al. 2018), zirconia $\left(\mathrm{ZrO}_{2}\right)$ (Yu et al. 2015) and titania ( $\left.\mathrm{TiO}_{2}\right)$ (Chakraborty et al. 2017). Among these materials, $\mathrm{SiO}_{2}$ is widely used as CHFMs (Chen et al. 2012; Jiang et al. 2017; Kai-Fan et al. 2018; Zhang et al. 2018). This is primarily due to its properties such as toughness, good abrasion, electrical insulation, high thermal stability, and its chemically inert attribute by the strength of the bond between the atoms (Hubadillah et al. 2018b).

Meanwhile, $\mathrm{Al}_{2} \mathrm{O}_{3}$ is another type of ceramic that has been widely used as CHFMs characterised by several advantages such as the equivalent thermal expansion coefficient to the corundum shell, excellent chemical stability and high temperature properties (Jiang et al. 2017; Lee et al. 2016, 2014; Zhu et al. 2015). In general, a combination of both $\mathrm{SiO}_{2}$ and $\mathrm{Al}_{2} \mathrm{O}_{3}$ ceramics can improve the overall characteristics of CHFM.

Previous studies have proved that adding polymer such as polyelectrolyte complexes (PEC) (Kai-Fan et al. 2018), polyethersulfone (PESf) and polyvinylpyrrolidone (PVP) (Zhu et al. 2015), poly(vinylidene fluoride) (PVDF) and polydimethylsiloxane (PDMS) (Zhang et al. 2018) improved the characteristics of CHFMs such as its anti-wetting characteristics and low surface energy for microscale topography by a cross-linked network (Kai-Fan et al. 2018; Zhang et al. 2018). For instance, Kai-Fan et al. (2018) obtained the shift of the functional group that occurred due to ether linkages between the hydroxyl groups of PEC and silanol indicating the formation of a chemical cross-linked network with $\mathrm{SiO}_{2}$ particles. Moreover, PESf is another type of polymer that has often been used as a binder in the fabrication of CHFM. However, previous studies using PESf as a binder undertaken by our research group focused on green $\mathrm{SiO}_{2}$ and clay mineral based CHFM (Hubadillah et al. 2018a, 2017a, 2017b; 2016a, 2016b, 2016c).

Even though it has been shown that the bore fluid flow rate is an important parameter in determining CHFM morphology and performance, it is frequently disregarded. In fact, the range of the flow rate constantly changes depending on the necessity of the research undertaken. Thus, in this study, the main objectives were to fabricate CHFM materials consisting of two types of ceramics $\left(\mathrm{SiO}_{2}\right.$ and $\left.\mathrm{Al}_{2} \mathrm{O}_{3}\right)$, PESf as binder and NMP as a solvent adopting several steps including ball milling, extrusion, phase inversion and a sintering process. During extrusion, the bore fluid flow rate was first, varied from $10-20 \mathrm{~mL} \mathrm{~min}^{-1}$ followed by analysing the characteristics of the fabricated CHFMs regarding their morphology and physical properties.

\section{MATERIALS AND METHODS}

The CHFMs were prepared using $\mathrm{SiO}_{2}$ powder of $99.8 \%$ purity of $25 \mu \mathrm{m}$ (Merck) and $\mathrm{Al}_{2} \mathrm{O}_{3}$ powder of $\leq 10 \mu \mathrm{m}$ (Merck). The polyethersulfone (PESf, Radel A300, Ameco Performance, USA) binder was dried to ensure that no moisture was trapped. The $N$-Methyl-2-pyrrolidone (NMP, Merck) was used as a solvent for the PESf without further purification, and the Arlacel P135 (polyethylene glycol 30-dipolyhydroxystearate, CRODA) was used as dispersant.

The procedure commenced by firstly, premixing the dope solution containing Arlacel P135 (1 wt. \%), NMP (44 wt. \%) and PESf (35 wt. \%) together using a hot plate stirrer (4 to $5 \mathrm{~h}$ ) at a fixed temperature $\left(60^{\circ} \mathrm{C}\right)$ and stirring speed (600 to $650 \mathrm{rpm})$. The dope solution was then placed into the ball mill along with the $\mathrm{SiO}_{2}$ powder (35 wt. \%), $\mathrm{Al}_{2} \mathrm{O}_{3}$ powder (15 wt. \%), water and grinding media. The ceramic suspension was then left to grind at $(15 \mathrm{~Hz})$ to ensure good dispersion of the $\mathrm{Al}_{2} \mathrm{O}_{3}$ powder and was then removed from the slip after $48 \mathrm{~h}$ before furthering the spinning process.

Next, the ceramic suspension was degassed (10 min) and immediately transferred into stainless steel syringes where the suspension was extruded through a tubein-orifice spinneret (outer diameter: $2.8 \mathrm{~mm}$ and inner diameter: $1.2 \mathrm{~mm})$ at a constant flow rate $\left(10 \mathrm{~mL} \mathrm{~min}^{-1}\right)$ and temperature $\left(25^{\circ} \mathrm{C}\right)$. Common tap water was used as an external and internal coagulant bath, and different bore fluid flow rate $\left(10,15\right.$ and $\left.20 \mathrm{~mL} \mathrm{~min}^{-1}\right)$ was supplied by a syringe pump (PHD 2000, Harvard Apparatus). All the CHFMs produced were held in a fibre collecting reservoir undergoing a phase inversion process. Following immersion overnight, the CHFMs were then removed from the reservoir, cut (20 cm length) and dried ( $4 \mathrm{~h})$ in a closed area at room temperature to prevent cracking.

Next, the CHFMs were sintered at low temperature before rising to $1200^{\circ} \mathrm{C}$ using a furnace (PLF 140/5) to improve the strength of the membranes. Firstly, the temperature was then increased to $600^{\circ} \mathrm{C}$ at a heating rate $\left(2^{\circ} \mathrm{C} \mathrm{min}^{-1}\right)$ for $5 \mathrm{~h}$ and was kept constant $(2 \mathrm{~h})$ to remove the polymer binder. Later, the temperature was then continuously increased to $1200^{\circ} \mathrm{C}$ with heating rate $\left(5^{\circ} \mathrm{C}\right.$ $\left.\mathrm{min}^{-1}\right)$ and soaking time $(3 \mathrm{~h})$ to allow growth between the ceramic particles. Finally, the temperature was cooled to room temperature at a cooling rate of $5^{\circ} \mathrm{C} \mathrm{min}{ }^{-1}$ as illustrated in Figure 1.

The cross-section and inner microstructure of CHFMs were observed employing field emission scanning electron microscopy (FESEM, JEOL JSM-7600F) where a cross-section of the sample was then prepared by immersing the fractured membrane in liquid nitrogen. Before characterised, it was coated with platinum. Next, the porosity of the CHFMs was measured using a porosity weight scale (Mettler Toledo). The Archimedes principle was used to calculate the porosity and density of the samples. First, the sample was weighed in a dry state before submerging in liquid, and then removed from the liquid and weighed. Finally, the obtained values were substituted to calculate the porosity (1) and density (2): 


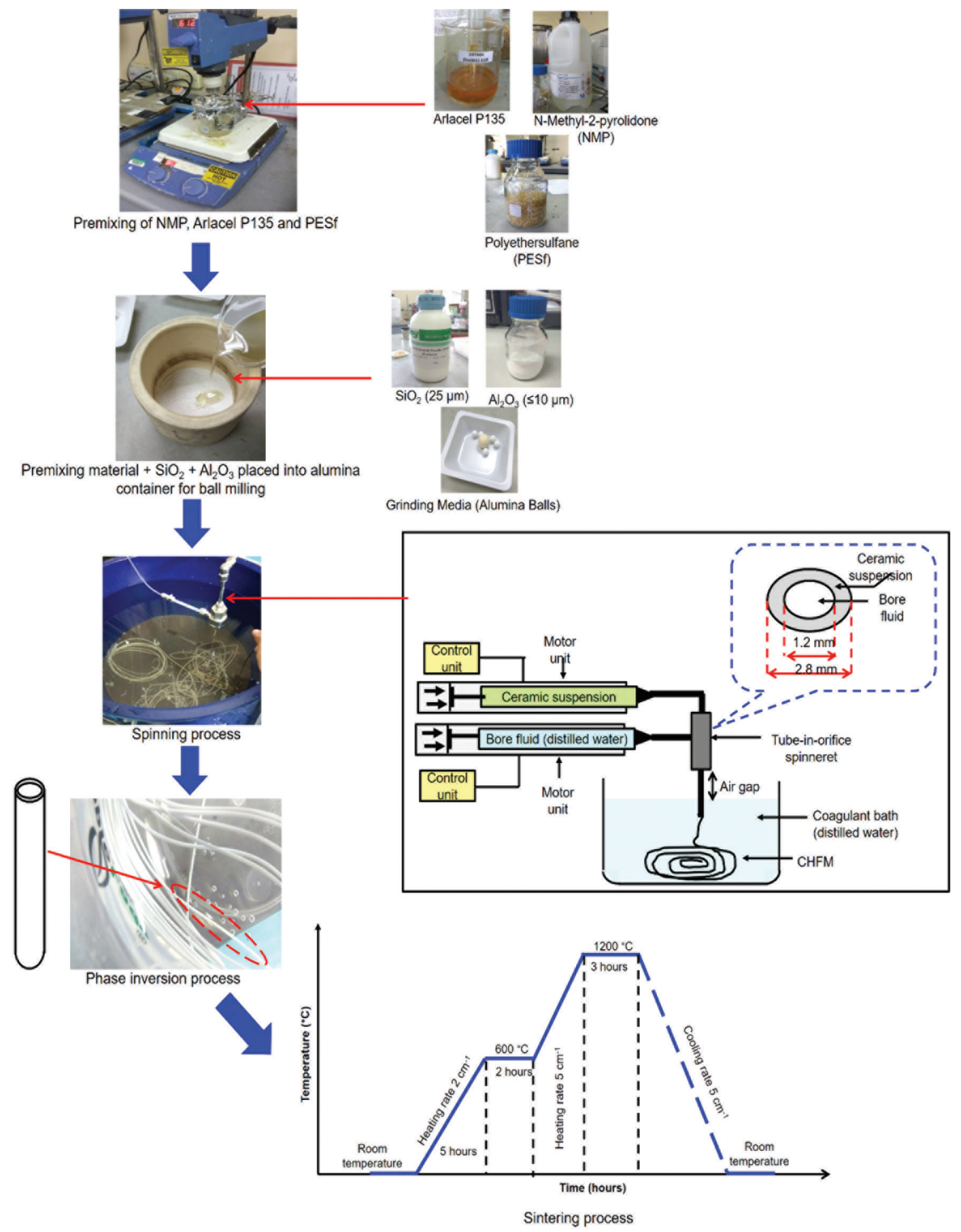

FIGURE 1. Ceramic hollow fibre membrane fabrication technique including premixing, ball milling, extrusion, phase inversion and sintering process

$\frac{W_{w}-W_{d}}{W_{w}-W_{s}} \times 100$

$\frac{W_{d}}{W_{d}-W_{s}} \times 100$ where $W_{d}$ is the weight of the dry sample and $W$ is the weight of the sample following submersion and $W_{w}$ is the weight of the sample after removing from the liquid. The topography and surface roughness of the CHFMs were then observed via atomic force microscopy (AFM, XE-Series Park Systems Model). The root means a square average 
of the height deviation $\left(R_{q}\right)$ which was taken from the mean image data plane, and the arithmetic average of the absolute values of the surface height deviations $\left(R_{a}\right)$ was obtained from the mean plane.

\section{RESULTS AND DISCUSSION}

\section{MORPHOLOGY OF CERAMIC HOLLOW FIBRE MEMBRANE}

Analysis of the cross-sectional and inner microstructure at different magnification is important to examine the effect of varied bore fluid flow rates pre and post-sintering for all fabricated CHFMs. It can be seen that the cross-section of all CHFMs had a hollow shaped microstructure (Figure 2(a $\mathrm{a}_{\mathrm{i}}$ )$\left.2\left(f_{i}\right)\right)$. Table 1 depicts the thickness of the hollow fibre wall for the CHFMs before being sintered (BF10-A, BF15-A and $\mathrm{BF} 20-\mathrm{A})$ and before decreasing after being sintered (BF10-B, $\mathrm{BF} 15-\mathrm{B}$ and BF20-B). The changes of the microstructure hollow membrane cross-section can be observed clearly at the higher magnification of $\times 100, \times 500$ and $\times 1000$ (Figure $\left.2\left(\mathrm{a}_{\mathrm{ii}-\mathrm{i} i \mathrm{i}}\right)-2\left(\mathrm{f}_{\mathrm{ii}-\mathrm{iv}}\right)\right)$. In this study, the rate of ceramic suspension extruded $\left(10 \mathrm{~mL} \mathrm{~min}^{-1}\right)$ was $\leq$ with the given bore fluid flow rate of $\left(10,15\right.$ and $\left.20 \mathrm{~mL} \mathrm{~min}^{-1}\right)$.
As shown in Figure 3, the mechanism of different bore fluid flow rate pre and post-sintering on the cross-section and inner microstructure of fabricated CHFMs is proposed based on previous studies performed by our research groups (Hubadillah et al. 2016c; Jamalludin et al. 2018). When the ceramic suspension was in contact with a coagulant (common tap water), the exchange rate of NMP (solvent) and tap water (non-solvent) bore fluid during phase separation affected the microstructure. The porous microstructure with an irregular shape of the particle can be seen in BF10-A at a similar rate of extruded ceramic suspension with a bore fluid flow rate of $\left(10 \mathrm{~mL} \mathrm{~min}^{-1}\right)$ (Figure 3(a)). Herein, the similar rate of NMP and tap water exchange assisted the movement of un-solidified particles in the inner region to form a porous structure of hollow membrane during extrusion. Regarding the shape of the hollow membrane, a more rigid lumen skin was formed for BF10-A and BF10-B due to sufficient demixing and complete solidification of PESf near the inner surface after sintering, besides the solidification rate and hydrodynamic forces. As a result, a fully circular contour structure was formed.

However, as the flow rate increased $(15$ and $20 \mathrm{~mL}$ $\mathrm{min}^{-1}$ ), the rate of NMP and tap water flow exchange
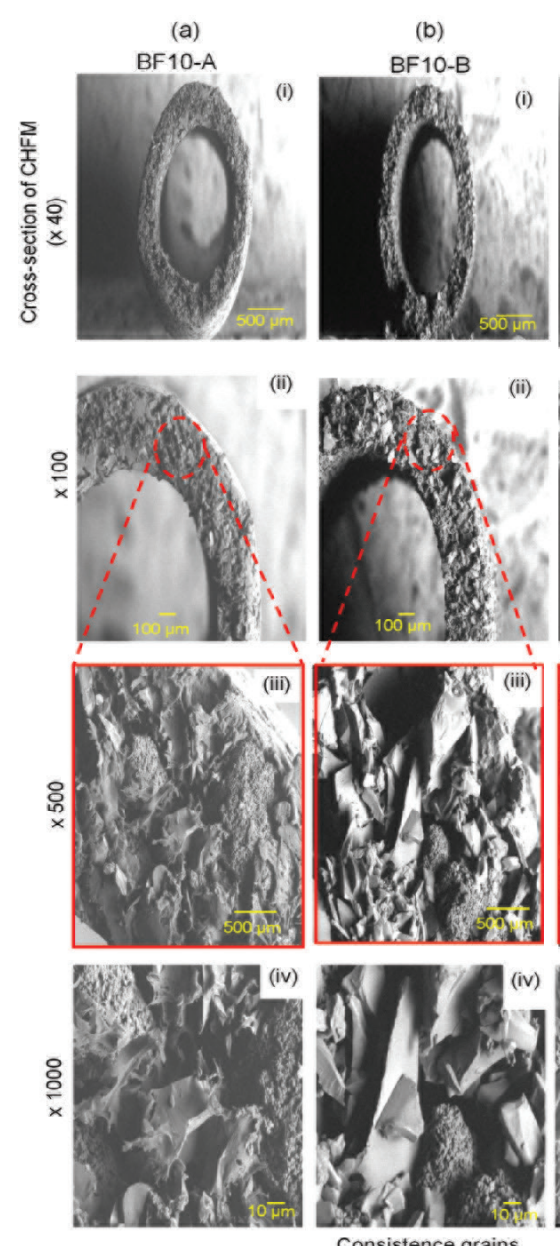

Consistence grains (c)
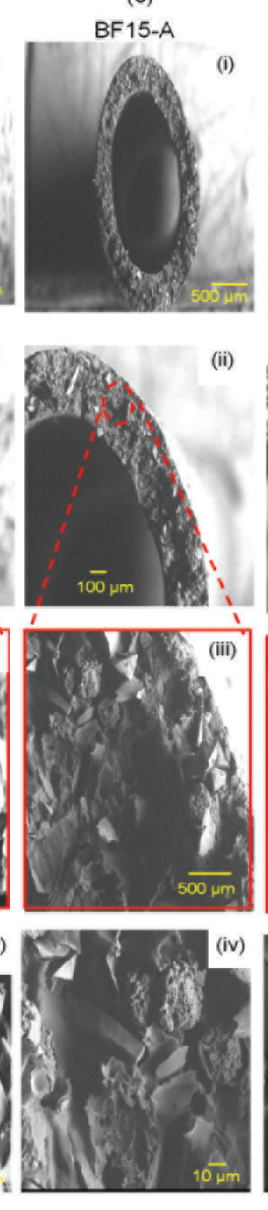

(d)
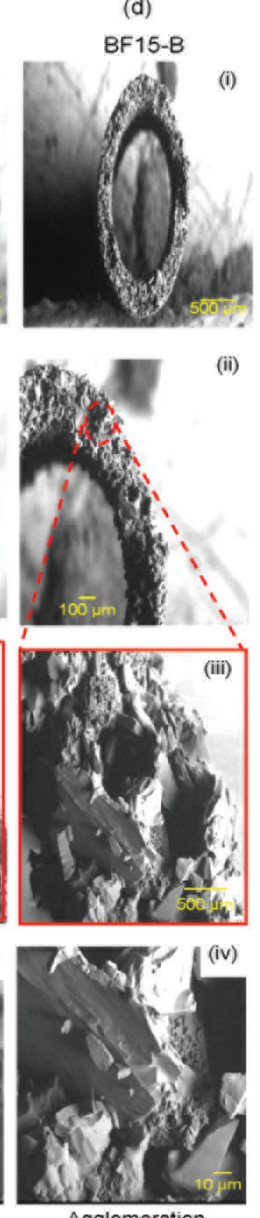

Agglomeration
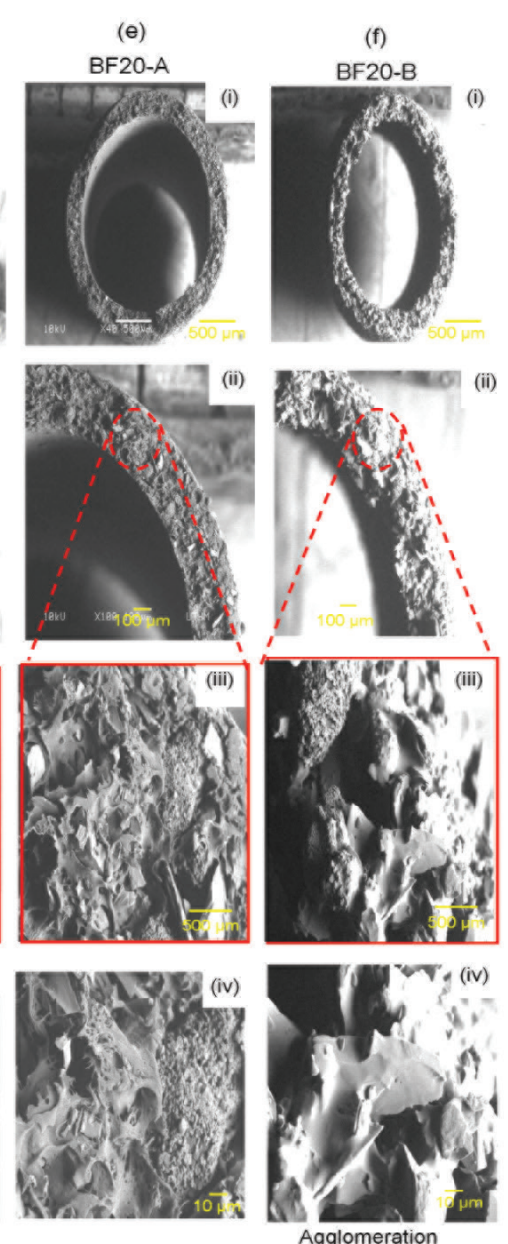

FIGURE 2. Cross-sectional morphology of ceramic hollow fibre membrane of (a) BF10-A (b) BF10-B (c) BF15-A (d) BF15-B (e) BF20-A and (f) BF20-B at different magnifications 
simultaneously decreased which in turn disturbed the kinetics of phase separation and contributed to the liquidliquid de-mixing (Figure 3(b)-3(c)). Under this condition, the higher bore fluid flow rate $\left(15\right.$ and $\left.20 \mathrm{~mL} \mathrm{~min}^{-1}\right)$ will facilitate the diffusion of the extruded ceramic suspension (slower flow rate of $10 \mathrm{~mL} \mathrm{~min}-1$ ) into the bore fluid to release pressure. Subsequently, the un-solidified particles were suppressed in the inner region due to the retardation of the hollow membrane inner surface. For the CHFMs with a higher bore fluid flow rate $\left(15\right.$ and $\left.20 \mathrm{~mL} \mathrm{~min}^{-1}\right)$, the circular hollow shape changed to become slightly oval. Therefore, insufficient de-mixing at high bore fluid flow rate leads to the incomplete solidification near the fibre inner surface that is unable to sustain the inward radial forces which produced an incomplete fibre inner contour.

Accordingly, this condition changed the porous structure of the hollow membranes to become agglomerated and with a dense cross-sectional surface with an irregular shape of the particles (BF15-A and BF20-A), besides decreasing the thickness of the hollow fibre. The CHFMs composition $\left(35 \% \mathrm{SiO}_{2}\right.$ and $\left.15 \% \mathrm{Al}_{2} \mathrm{O}_{3}\right)$ also caused the membrane to become brittle since the quartz structure of $\mathrm{SiO}_{2}$ is strongly brittle. Following the sintering process, the microstructure of BF10-B, BF15-B and BF20-B was shifted to the dense surface, proving that the sintering process only increased the dense layer and did not change the entire structure of the hollow membranes. In fact, the thickness of all the hollow fibres had a marginal percentage change after sintering (13-14\%). Even though the sintering process was applied, the heat treatment was the only function to increase the density of the dense layer, which was similar with earlier studies on the fabrication of CHFMs using different bore fluid (Tan et al. 2011).

Additionally, the proposed mechanism in Figure 3 also correlated with the decreasing thickness of the hollow fibre as the bore fluid flow rates increased (Table 1). Therefore, the major factor that affected the microstructure of hollow fibres was the bore fluid flow rates during the spinning process. It is also suggesting that, when tap water is used as bore fluid, the NMP-tap water exchange rate on the inner surface is close to the outer surface, leading to similar porous structures of both regions (sandwich structure) and decreases the thickness of the hollow fibre (Tan et al. $2011,2005)$. The higher composition of NMP solvent (44\%) could also produce a slack hollow membrane without a uniform microstructure. In general, the porous and dense structure of BF10-B was still better compared to BF15-B and $\mathrm{BF} 20-\mathrm{B}$, which proved the interrelated relationship between the ceramic suspensions extruded and the bore fluid flow rate.

\section{PHYSICAL PROPERTIES OF CERAMIC HOLLOW FIBRE MEMBRANE}

The physical analysis only focused on BF10-B, BF15-B and BF20-B since the sintering process is important in improving the attachment between $\mathrm{SiO}_{2}$ and $\mathrm{Al}_{2} \mathrm{O}_{3}$ and other CHFM materials, besides the effects of the bore fluid flow rate. Investigating the topography of the CHFMs by AFM is significant since the surface roughness determines the hollow membranes function in avoiding the fouling mechanism for separation applications. The

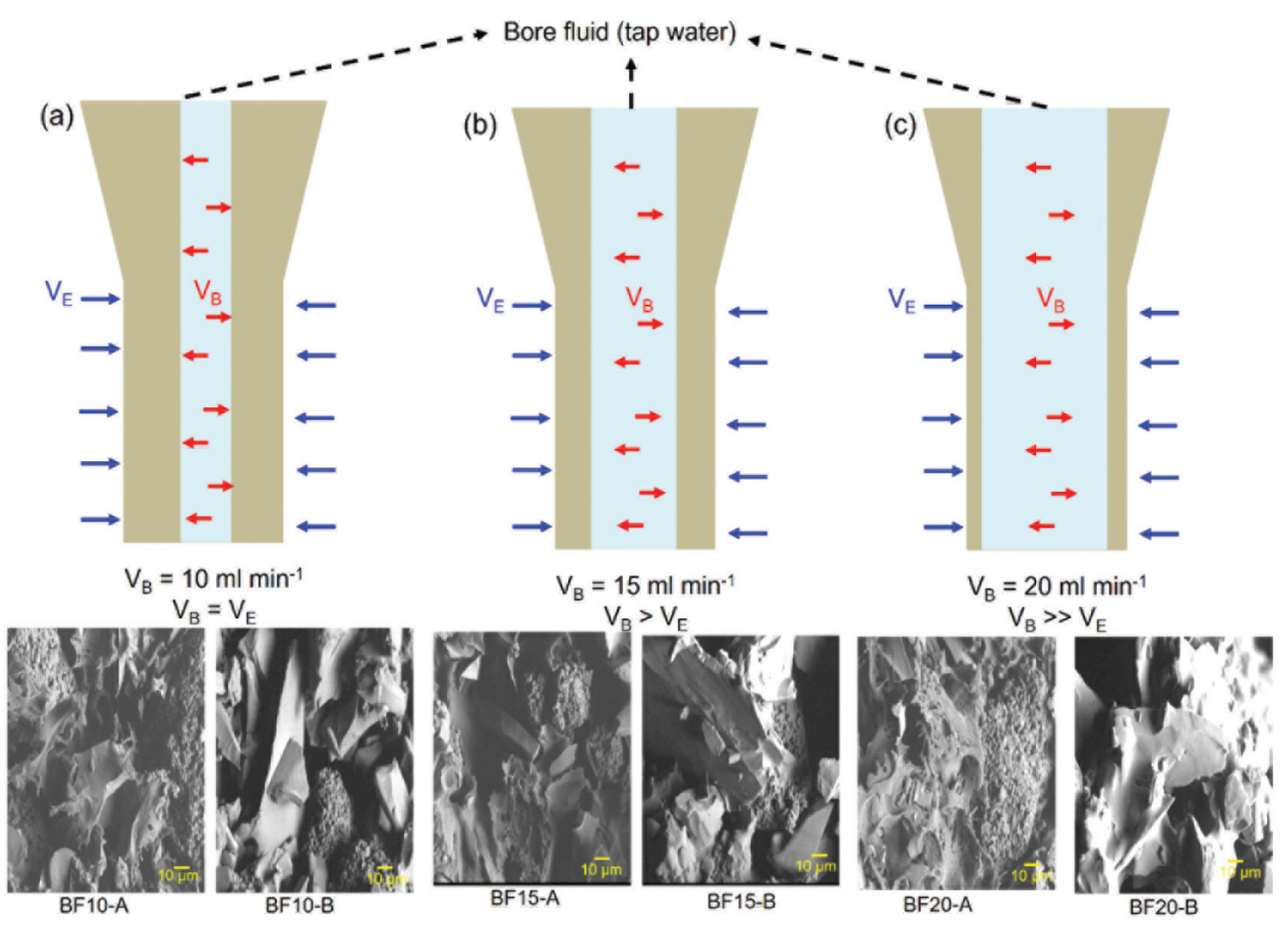

FIGURE 3. Proposed mechanism of different bore fluid flow rate for fabricated CHFMs

(a) BF10-A and BF10-B, (b) BF15-A and BF15-B (c) BF20-A and BF20-B 
three-dimensional topographical images measured the $R_{q}$ and $R_{a}$ values (Figure 4(a)-4(d), Table 1) where the brightest regions represent the highest points of the hollow membranes surface, while the darkest regions correspond to the pore entrances. Here, BF10-B had the highest values of both $\mathrm{R}_{\mathrm{q}}$ and $\mathrm{R}_{\mathrm{a}}$ although both of these values decreased as the bore fluid flow rate increased (15 and $\left.20 \mathrm{~mL} \mathrm{~min}^{-1}\right)$. Aside from that, measuring porosity and density is another important characteristic to investigate. As the bore fluid flow rate increased, the porosity of all CHFMs decreased, whereas, the density increased (Figure 4(e), Table 1). This is in accordance with the morphology and cross-sectional results as discussed earlier. As expected, the surface roughness characteristics are in line with the porosity and density values.

The darkest regions that correspond to the pore entrances of BF10-B were found to be larger thereby proving that the hollow membrane had a porous structure compared to BF15-B and BF20-B after sintering. This is also confirmed by the $\mathrm{R}_{\mathrm{q}}, \mathrm{R}_{\mathrm{a}}$ and porosity values. The unsolidified particles in $\mathrm{BF} 10-\mathrm{B}$ have been suppressed smoothly in the inner region during extrusion due to the retardation of the hollow membrane inner surface at a flow rate of $10 \mathrm{~mL} \mathrm{~min}^{-1}$. The good solidification of all particles during sintering produced a porous hollow structure surface and decreased the density of the membrane. Hence, $R_{q}$, $\mathrm{R}_{\mathrm{a}}$ and porosity values increased. However, insufficient de-mixing occurred at a higher flow rate $(15$ and $20 \mathrm{~mL}$ $\mathrm{min}^{-1}$ ). Therefore, as a result, the darkest regions of the pore entrances also decreased with $\mathrm{R}_{\mathrm{q}}, \mathrm{R}_{\mathrm{a}}$ and porosity values. The suppression of unsolidified particles in the inner region cannot occur completely during extrusion and increased the density value. This condition changed the porous hollow membranes to become agglomerated with a dense surface with an irregular shape of particles following sintering for BF15-A and BF20-A. Overall, the porosity of BF10-B

(a)

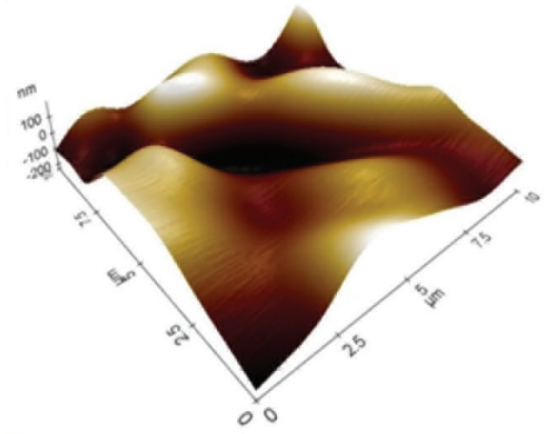

(b)

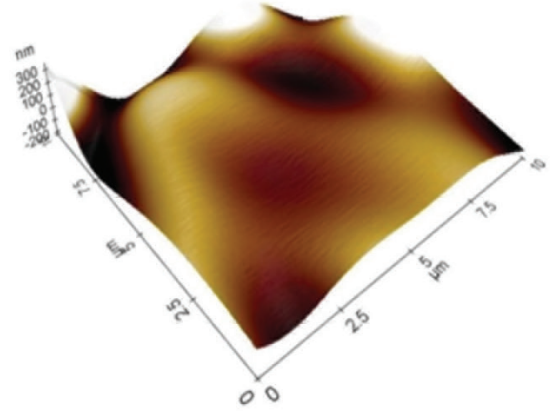

(d)

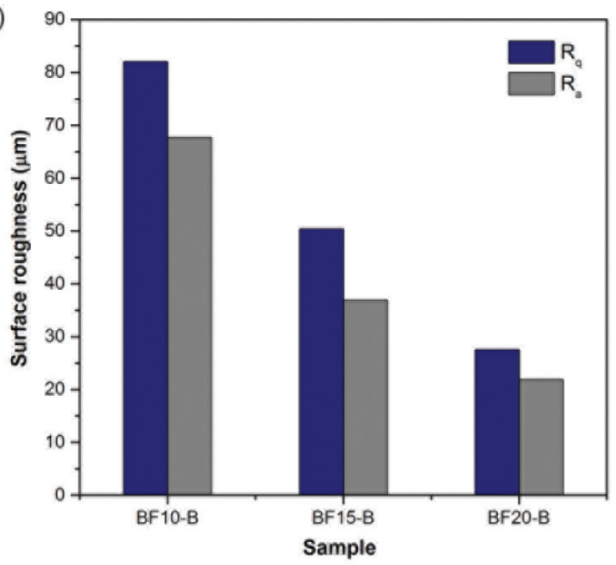

(c)

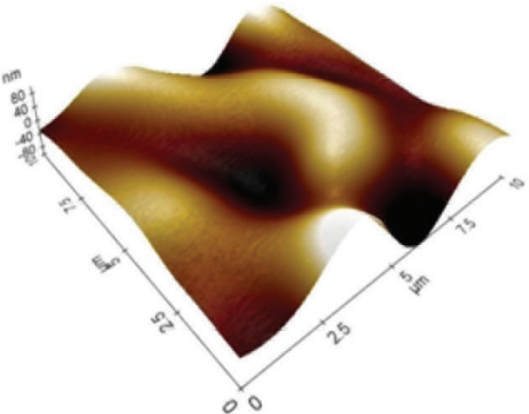

(e)

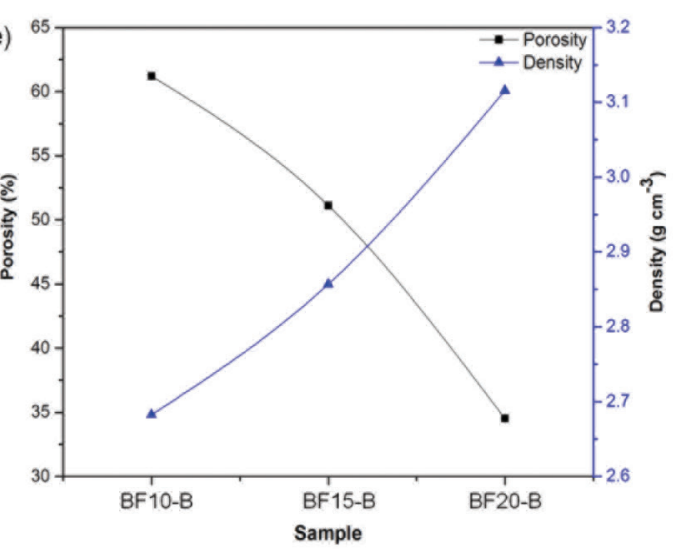

FIGURE 4. Physical properties including (a) topography of BF10-B (b) topography of BF15-B (c) topography of BF20-B (d) surface roughness (e) porosity and density of ceramic hollow fibre membrane 


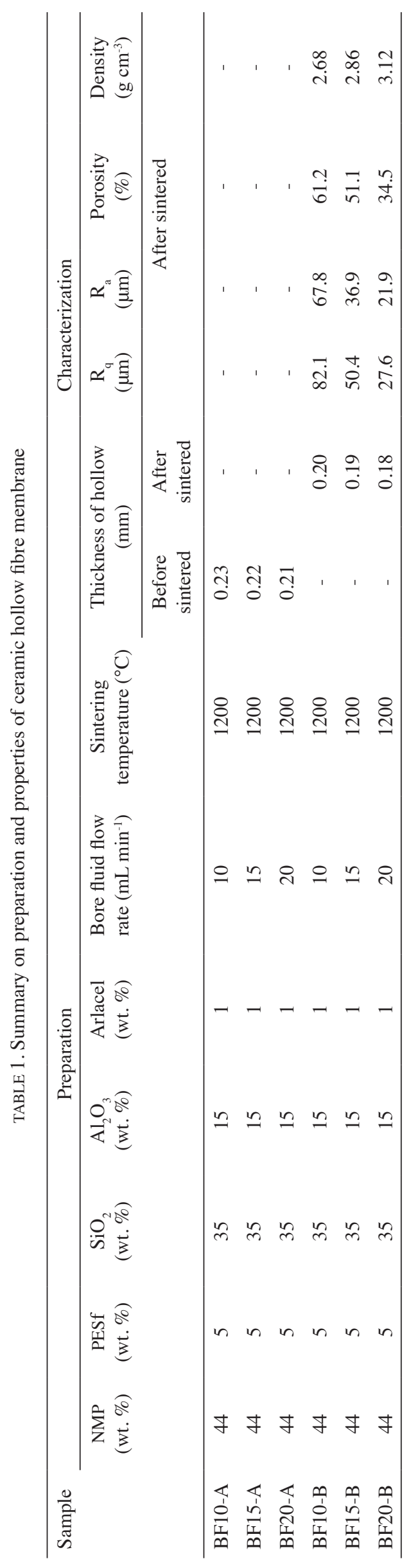


$(61.2 \%)$ is still sufficient to be used in the real application since the ideal porosity of porous ceramic membrane to minimise the pressure drop is relatively larger and above 40\% (Honda et al. 2010; Hubadillah et al. 2018a). Additionally, the properties of CHFMs obtained in this study similar with previous study on microstructure and physical of $\mathrm{Al}_{2} \mathrm{O}_{3}$, double layers $\mathrm{Al}_{2} \mathrm{O}_{3} / \mathrm{Al}_{2} \mathrm{O}_{3}$ and $\mathrm{Al}_{2} \mathrm{O}_{3} /$ $\mathrm{SiO}_{2}$ sintered body via hot isostatic pressing microwave and natural drying (Alias et al. 2019; Ismail et al. 2012).

\section{CONCLUSION}

The CHFM was successfully fabricated by extrusion, phase inversion and sintering using two types of ceramics $\left(\mathrm{SiO}_{2}\right.$ and $\mathrm{Al}_{2} \mathrm{O}_{3}$ ). Varying the bore fluid flow rate from 10,15 and $20 \mathrm{~mL} \mathrm{~min}^{-1}$ gave a significant effect on the CHFM properties. The CHFM extruded at $10 \mathrm{~mL} \mathrm{~min}^{-1}$ was found to have the best morphology and physical properties with porous cross-sectional microstructure, highest pore entrance, good topography, porosity, and lowest density. The fabricated CHFM has the potential to be used as commercial CHFM for water separation.

\section{ACKNOWLEDGEMENTS}

This work was financially supported by the Advanced Materials and Manufacturing Centre (AMMC), Faculty of Mechanical and Manufacturing Engineering, Universiti Tun Hussein Onn Malaysia under the Transdisciplinary Research Grant Scheme (TRGS Vot T001), Post Doc Grant (D005) and the Ministry of Higher Education Malaysia (MOHE).

\section{REFERENCES}

Alias, S.S., Harun, Z. \& Ismail, N.F. 2019. Microstructure and physical characterization of alumina-sintered body via hot isostatic pressing. J. Aus. Ceram. Soc. Volume (Issue): 1-7.

Bao-li, L., Dan-ran, L., Jin-hui, C., Zeng-yong, L., Guang-hui, W., Xu-ping, Z., Fei, X. \& Yan-qing, L. 2018. Hollow core microfiber for optical wave guiding and microfluidic manipulation. Sensor Actuat. B-Chem. 262: 953-957.

Chakraborty, S., Loutatidou, S., Palmisano, G., Kujawa, J., Mavukkandy, M.O., Al-Gharabli, S., Curcio, E. \& Arafat, H.A. 2017. Photocatalytic hollow fiber membranes for the degradation of pharmaceutical compounds in wastewater. $J$. Environ. Chem. Eng. 5: 5014-5024.

Chen, Q., Wang, S. \& Li, Z. 2012. Fabrication and characterization of aluminum silicate fiber-Reinforced hollow mesoporous silica microspheres composites. Micropor. Mesopor. Mat. 152: 104-109.

Harabi, A., Zenikheri, F., Boudaira, B., Bouzerara, F., Guechi, A. \& Foughali, L. 2014. A new and economic approach to fabricate resistant porous membrane supports using kaolin and CaCO3. J. Eur. Ceram. Soc. 34: 1329-1340.

Honda, S., Ogihara, Y., Hashimoto, S. \& Iwamoto, Y. 2010. Thermal shock properties of porous alumina for support carrier of hydrogen membrane materials. Advances in Bioceramics and Porous Ceramics III: Ceramic Engineering and Science Proceedings 31: 127-137.
Hubadillah, S.K., Othman, M.H.D., Ismail, A., Rahman, M.A., Jaafar, J., Iwamoto, Y., Honda, S., Dzahir, M.I.H.M. \& Yusop, M.Z.M. 2018a. Fabrication of low cost, green silica based ceramic hollow fibre membrane prepared from waste rice husk for water filtration application. Ceram. Int. 44: 10498-10509.

Hubadillah, S.K., Othman, M.H.D., Matsuura, T., Rahman, M.A., Harun, Z., Jaafar, J. \& Nomura, M. 2018b. Fabrications and applications of low cost ceramic membrane from kaolin: A comprehensive review. Ceram. Int. 44: 4538-4560.

Hubadillah, S.K., Othman, M.H.D., Harun, Z., Ismail, A., Rahman, M.A. \& Jaafar, J. 2017a. A novel green ceramic hollow fiber membrane (CHFM) derived from rice husk ash as combined adsorbent-separator for efficient heavy metals removal. Ceram. Int. 43: 4716-4720.

Hubadillah, S.K., Othman, M.H.D., Harun, Z., Ismail, A., Rahman, M.A., Jaafar, J., Jamil, S.M. \& Mohtor, N.H. 2017b. Superhydrophilic, low cost kaolin-based hollow fibre membranes for efficient oily-wastewater separation. Mater. Lett. 191: 119-122.

Hubadillah, S.K., Harun, Z., Othman, M.H.D., Ismail, A. \& Gani, P. 2016a. Effect of kaolin particle size and loading on the characteristics of kaolin ceramic support prepared via phase inversion technique. J. Asian Ceram. Soc. 4: 164-177.

Hubadillah, S.K., Harun, Z., Othman, M.H.D., Ismail, A., Salleh, W.N.W., Basri, H., Yunos, M.Z.\& Gani, P. 2016b. Preparation and characterization of low cost porous ceramic membrane support from kaolin using phase inversion/sintering technique for gas separation: Effect of kaolin content and non-solvent coagulant bath. Chem. Eng. Res. Des. 112: 24-35.

Hubadillah, S.K., Othman, M.H.D., Harun, Z., Ismail, A., Iwamoto, Y., Honda, S., Rahman, M.A., Jaafar, J., Gani, P. \& Sokri, M.N.M. 2016c. Effect of fabrication parameters on physical properties of metakaolin-based ceramic hollow fibre membrane (CHFM). Ceram. Int. 42: 15547-15558.

Ismail,A.F. \& David,L. 2001. A review on the latest development of carbon membranes for gas separation. J. Membrane Sci. 193: 1-18.

Ismail, N.F., Harun, Z. \& Badarulzaman, N.A. 2012. A comparative study of double layers $\mathrm{Al}_{2} \mathrm{O}_{3} / \mathrm{Al}_{2} \mathrm{O}_{3}$ and $\mathrm{Al}_{2} \mathrm{O}_{3} /$ $\mathrm{SiO}_{2}$ prepared by microwave and natural drying. International Journal of Integrated Engineering 4: 16-21.

Jamalludin, M.R., Harun,Z., Othman, M.H.D., Hubadillah, S.K., Yunos, M.Z.\& Ismail, A.F. 2018. Morphology and property study of green ceramic hollow fiber membrane derived from waste sugarcane bagasse ash (WSBA). Ceram. Int. 44: 18450-18461.

Jiang, W., Li, K., Xiao, J. \& Lou, L. 2017. Effect of silica fiber on the mechanical and chemical behavior of alumina-based ceramic core material. J. Asian Ceram. Soc. 5: 410-417.

Kai-Fan, C., Pei-Yao, Z., Jia-Kai, W., Nai-Xin, W., Quan-Fu, A. \& Kueir-Rarn, L. 2018. Polyelectrolyte complexes/silica hybrid hollow fiber membrane for fusel oils pervaporation dehydration processes. J. Membrane Sci. 545: 284-291.

Kingsbury, B.F. \& Li, K. 2009. A morphological study of ceramic hollow fibre membranes. J. Membrane Sci. 328: 134-140.

Lee, M., Wang, B. \& Li, K. 2016. New designs of ceramic hollow fibres toward broadened applications. J. Membrane Sci. 503: 48-58.

Lee, M., Wu, Z., Wang, R. \& Li, K. 2014. Micro-structured alumina hollow fibre membranes-Potential applications in wastewater treatment. J. Membrane Sci. 461: 39-48. 
Maaskant, E., de Wit, P. \& Benes, N.E. 2018. Direct interfacial polymerization onto thin ceramic hollow fibers. J. Membrane Sci. 550: 296-301.

Tan, X., Liu, N., Meng, B. \& Liu, S. 2011. Morphology control of the perovskite hollow fibre membranes for oxygen separation using different bore fluids. J. Membrane Sci. 378: 308-318.

Tan, X., Liu, Y. \& Li, K. 2005. Preparation of LSCF ceramic hollow-fiber membranes for oxygen production by a phaseinversion/sintering technique. Ind. Eng. Chem. Res. 44: 61-66.

Wang, P. \& Chung, T.S. 2012. Design and fabrication of lotusroot-like multi-bore hollow fiber membrane for direct contact membrane distillation. J. Membrane Sci. 421: 361-374.

Yu, X., An, L., Yang, J., Tu, S.T. \& Yan, J. 2015. CO 2 capture using a superhydrophobic ceramic membrane contactor. $J$. Membrane Sci. 496: 1-12.

Zhang, H., Li, B., Sun, D., Miao, X. \& Gu, Y. 2018. SiO 2 -PDMSPVDF hollow fiber membrane with high flux for vacuum membrane distillation. Desalination 429: 33-43.

Zhu, Z., Xiao, J., He, W., Wang, T., Wei, Z. \& Dong, Y. 2015. A phase-inversion casting process for preparation of tubular porous alumina ceramic membranes. J. Eur. Ceram. Soc. 35: 3187-3194.
Siti Salwa Alias, Zawati Harun*, Ahmad Nazreen Ahmad Ismail \& Noor Hasliza Kamarudin

Advanced Manufacturing and Materials Centre (AMMC)

Institute Integrated Engineering (I2E)

Universiti Tun Hussein Onn Malaysia

86400 Parit Raja, Johor Darul Takzim Malaysia

Zawati Harun*, Ahmad Nazreen Ahmad Ismail \& Noor Hasliza Kamarudin

Department of Materials and Design Engineering

Faculty of Mechanical and Manufacturing Engineering

Universiti Tun Hussein Onn Malaysia

86400 Parit Raja, Johor Darul Takzim

Malaysia

*Corresponding author; email: zawati@uthm.edu.my

Received: 6 November 2018

Accepted: 9 April 2019 